Article

\title{
Trends of the Time: An Examination of Judicial Waiver in One State
}

\author{
Alison S. Burke \\ Department of Criminology and Criminal Justice, Southern Oregon University, 1250 Siskiyou Blvd, \\ Ashland, OR 97520, USA; E-Mail: burkea@sou.edu; Tel.: +1-541-552-8288 \\ Academic Editor: Martin J. Bull
}

Received: 9 March 2015 / Accepted: 10 September 2015 / Published: 17 September 2015

\begin{abstract}
During the 1990s and 2000s, nearly every state revised its laws or adopted new legislation facilitating the transfer of juvenile offenders from juvenile court to criminal court. Previously, transfer was reserved for the "worst juveniles", or those youths who were charged with serious violent offenses. This paper compares and contrasts girls and boys who were judicially waived to adult court in one state from 1994 to 2000 . These data suggest that there may be other factors that influence judicial decision-making on the issue of transfer. Policy considerations are also discussed.
\end{abstract}

Keywords: judicial waiver; gender and juvenile justice; juvenile court

\section{Introduction}

Since its inception, the juvenile court has become more formalized, accountability driven, and "criminalized" [1-3]. The juvenile court was created to function under the parens patriae doctrine, which meant that it was acting in the best interest of the child thus giving the court the jurisdiction to pursue child welfare [4,5]. However, states in the 1990s authorized different mechanisms to allow juvenile offenders to be $\mathrm{p}$ rosecuted in the same manner as adult offenders. Currently, all states have at least one mechanism that allows youth to be transferred from juvenile court to adult criminal court [6]. The requirements vary across states, but typically a combination of determining factors is considered. These include: current offense, prior record, and amenability to treatment. However, it has been argued that gender also plays a role and girls are treated differently than boys in the juvenile justice system [7-10]. The current study explores whether the genders were treated equally or if gender was an influential variable in judicial waiver decisions in the 1990s. 


\section{Literature Review}

There are several mechanisms by which a juvenile can be transferred to adult criminal court: prosecutorial, legislative, and judicial waiver. Prosecutorial waiver also is referred to as "Direct File" and "Concurrent Jurisdiction". With this waiver mechanism, the legislature grants a prosecutor the discretion to determine in which court to file charges against the juvenile $[11,12]$. The prosecutor, or district attorney, can choose to file charges in juvenile court or adult criminal court. This procedure does not require a transfer hearing, so the defense is not accorded the opportunity to present evidence in an attempt to avoid the transfer $[11,13]$.

Legislative waiver, or statutory waiver, identifies certain offenses which have been mandated by state law to be excluded from juvenile court jurisdiction [13]. It is utilized as a method to decrease or eliminate the discretionary powers of judges and prosecutors $[11,13,14]$.

Judicial waiver affords the juvenile court judge the authority to transfer a case to adult criminal court $[1,11,13,14]$. There are three types of judicial waiver, discretionary, presumptive, and mandatory. Discretionary (regular) transfer allows a judge to transfer a juvenile from juvenile court to adult criminal court [15]. With this type of transfer, the burden of proof rests with the state and the prosecutor must confirm that the juvenile is not amenable to treatment [15]. In Kent v. United States (383 U.S. 541, 566-67 [1966]), the Supreme Court outlined threshold criteria that must be met before a court can consider waiving a case. These waiver statutes typically include minimum age, specified type of offense, a sufficiently serious prior record, or a combination of the three [6].

In Arizona, eight is the minimum age specified for discretionary waiver. Arizona Rev. Statute Sec. 8-327 states that the juvenile court must hold a hearing to consider transferring the jurisdiction of a child accused of committing any felony. The court can transfer the case if there is a preponderance of evidence that the youth committed the alleged offense and if the safety of the public is best served by the transfer [6].

Presumptive waiver involves shifting the burden of proof from the State to the defendant [15]. It is presumptive because it is presumed that it will occur unless the youth can meet the burden of proof and provide justifiable reason to remain in juvenile court [15]. If the youth is unable to show just cause or sufficient reason why the case should be tried in juvenile court, the case will be transferred and tried in adult court.

The third type of judicial waiver is mandatory waiver. Mandatory waiver specifies that a juvenile judge must automatically transfer to adult court juvenile offenders who meet certain criteria, such as age and current offense [6]. In these cases, the role of the judge is simply to confirm that the waiver criteria are met and then to transfer the case to adult court. Mandatory waiver attempts to remove all discretionary powers from the juvenile court judge in transfer proceedings [16]. Arizona does not utilize this type of transfer mechanism. Historically, judicial waiver has been the most common transfer method; therefore the current study examines this transfer mechanism to determine if it was applied equally and consistently between boys and girls. 


\section{The Influence of Variables on Judicial Decisions}

Research suggests that judges apply waiver decisions in an arbitrary and discriminatory manner [11-17]. Some decisions are based upon legal factors, while others are driven by extralegal factors. Legal factors include variables such as seriousness of current offense and number of prior offenses. Prior to the youth violence surge of the mid 1980s, property crime accounted for the largest number of youth transferred to adult court [18,19]. Trends in the mid-1990s (from 1993-1997) demonstrated that violent offenses made up the largest group of judicially waived youth [20-22]. However, by the end of the 1990 s and the beginning of the millennium, juvenile courts once again waived more property offenders than person offenders [23,24]. In general, research suggests that the more serious the offense committed and the more extensive the youth's prior record, the greater the likelihood of transfer [25]. There is evidence that legal rules govern sentencing decisions and "sentencing outcomes are primarily the result of legal rules and criteria applied equally to all classes and races” ([26], p. 1161).

Conversely, extra legal factors such as age, gender, race, and other demographic variables or juvenile characteristics have been found to influence sentencing decisions [27-29]. For example, Fagan and Deschenes (1990) found that prosecutors in Phoenix sought transfers for nearly all seventeen year olds for the purpose of obtaining a longer sentence in a secure facility since the jurisdiction of the juvenile court ended at eighteen [17].

In regard to gender and race, research suggests that girls and minorities are particularly affected by punitive juvenile justice laws Historically, girls received harsh penalties for their moral and sexual transgressions [30,31]. However, research also has found that girls who were referred to court for delinquent offenses instead of status offenses received less severe sanctions than delinquent boys. Earlier research indicated that female delinquents were less likely than male delinquents to be formally charged with criminal offenses, and if they were charged, girls were less likely to be incarcerated or institutionalized $[32,33]$. The reason for these different outcomes might be the result of more complicated interactions of race, gender, and other extra legal factors, and not just the effects of gender.

Similarly, race is very strongly related to sentencing outcomes. Research has documented that minority overrepresentation occurs at all stages of the juvenile justice system: referral, detention, formal charging, adjudication, and disposition [34-37]. This is referred to as disproportionate minority contact (DMC). In the 1988 amendments to the Juvenile Justice and Delinquency Prevention (JJDP) Act of 1974 (Public Law 93-415, 42 U.S.C. 5601 et seq.), Congress required States to address disproportionate minority confinement in their State plans. In the 1992 amendments to the JJDP Act, DMC was elevated to a core requirement and the eligibility of future funding was tied to State compliance with the Act [38].

States participating in the Federal Formula Grants Program were required to determine whether DMC existed within their justice system, identify the causes, and develop strategies designed to correct the issue [39]. The statute mandated the reduction of racial disparities "regardless of whether those disparities were motivated by intentional discrimination or justified by 'legitimate' agency interests" ([40], p. 374). States failing to make progress or, at the very least show that they were making an effort toward this endeavor, risked losing their funds [41].

Even though states attempted to address the issue, minority youth continued to have disproportionate contact with the justice system. According to Sikmund, Sladky, and Kang (2015), this continues to be a trend in many states [42]. In the mid-1990s, minority youth accounted for over half of youth waived 
to adult court [43]. Since the current study examines a population from the mid-1990s, it would not be surprising to find the same percentage represented in the sample.

Although there is support for the effects of the independent influence of legal and extra legal variables, there are those who find that both legal and extra legal variables are weighted evenly, and that judges take a wide variety of factors into account when determining a sentence [44,45]. Research suggests that judges consider the youth's blameworthiness, the degree of harm caused to the victim, the protection of the community, and the pragmatic implications of a sentencing decision [46]. Judicial waiver decisions individualize justice and allow the judge to consider all relevant aspects of the case [47]. The judge considers the seriousness of the crime, the maturity of the offender, and the level of aggression and violence exhibited during the commission of the crime [48]. The judge also determines the youth's amenability to treatment, the safety of the community, and the harm done to the victim and the victim's family [47].

Because judges often lack information to determine the degree of dangerousness, culpability, and amenability to treatment, it has been argued that they revert to stereotypes about a youth's characteristics to make their rulings [46]. These extralegal variables and stereotypes may reflect their belief of traditional gender roles and the appropriate behavior for girls [8].

\section{Theoretical Perspective}

Since the beginning of the juvenile court, there has been debate concerning the factors that most influence judicial decision making. Judges often have been accused of basing their decision making on vindictiveness, bias, or even a paternalistic protectiveness [49]. The term "paternalistic justice" has been used to explain the difference in the treatment accorded male and female delinquents based on the traditional gender roles adopted by society [50,51]. It is implied that girls who behave in ways that are proper and appropriate of the traditional female roles of purity and submission receive preferential treatment and more lenient sentences. Leiber and Mack (2003) suggest that, “...decision makers treat females more leniently because they have been socialized to protect females, or they have stereotypical beliefs that females do not engage in criminal behavior" ([9], p. 59).

Conversely, girls who violate these roles may be dealt with more severely than boys who commit the same offense [49]. This response supports the notion of the "evil woman" and "vengeful equity" hypothesis. The evil woman perspective suggests that girls are treated more harshly than boys who commit similar offenses because these girls have not only violated the law, but have also violated acceptable gender roles [30]. The vengeful equity perspective postulates that girls are treated as though they were boys "particularly when the outcome is punitive, in the name of equal justice" ([50], p. 18).

The past few decades have witnessed a significant increase in the number of girls entering the system [52]. In 1980, girls accounted for 20 percent of all juvenile arrests, and this number increased to 30 percent in 2008 [20,53]. In 2008, the arrest rate for boys was only 4 percent more than it was in 1980; yet for the same year, the arrest rate for girls was 80 percent higher than the 1980 level [20]. Although arrests of juveniles decreased 2.8 percent from 2007 to 2008, the arrest rate for juvenile girls increased [20]. 
The juvenile justice system continues to be dominated by boys, yet despite their increased presence, girls remain largely marginalized a majority of researchers. In a correctional system designed for boys and men, girls have proceeded through the juvenile justice system as the "forgotten few" [54].

Although transfer studies explore the issue of judicial waiver $[6,11,55]$, the literature is lacking in regard to how judicial waiver decisions affect female youth. For example, an empirical study of 330 judicial waiver decisions conducted by Podkopacz and Feld (1996) does not refer to girls within the analysis [56]. In his study of transferred youth, Jordan (2005) noted that there were girls present in his study, but the number was too small to be analyzed separately [16]. Ninety-five percent of the youth waived between 1990 and 1999 were boys [20] but there is little research that examines the five percent of girls. Feld (2009) contends that the small number of girls transferred by race "are too small for any meaningful comparison" ([57], p. 247). Girls have proceeded through the juvenile justice system as the "forgotten few" [55]. The lack of attention to gender is particularly remarkable since the arrest rate for girls continues to increase [20,53].

There is little research that examines the specific effect that judicial waiver legislation has on female and minority youth. For example, research suggests that girls and minorities are being particularly affected by punitive juvenile justice laws [34] yet the interaction of gender and race requires further study. McDonald and Chesney-Lind (2001) contend that the juvenile justice system needs to consider the effect of gender and race if it intends to act in the "best interest" of girls [10].

\section{Current Study}

The current study examines judicial waiver of girls and boys and determines if girls are treated more harshly or more leniently than their male counterparts. It also explores the variables that most influence judicial waiver for both genders and seeks to add to the literature about judicial waiver.

\section{Methods}

The present study examined the effects of legal and extralegal factors on the decision to judicially waive youth in juvenile court in Arizona between 1994-2000. The peak year for judicial transfer was 1994. This number decreased in subsequent years and was $29 \%$ lower in 2004 than it was in 1994 . The data were obtained from the National Juvenile Court Data Archive which is maintained by the National Center for Juvenile Justice for the Office of Juvenile Justice and Delinquency Prevention ${ }^{1}$ [58], and were comprised of two groups: youth who were transferred to adult court and youth who were retained in juvenile court. The data set provided 556,873 cases and for the purposes of this study, these were then refined to cases involving only felony offenses and those juveniles who were judicially waived to adult court. The sample was stratified based on transfer and gender. The study utilized the cases of all girls who were judicially transferred for felony offenses (the full population within the data set,

1 The data utilized in this publication were housed in and made available by the National Juvenile Court Data Archive which is maintained by the National Center for Juvenile Justice in Pittsburgh, Pennsylvania, and supported by a grant from the Office of Juvenile Justice and Delinquency Prevention, U.S. Department of Justice. The data were originally collected by the Arizona Supreme Court, Administrative Office of the Courts. Neither the Arizona Supreme Court, Administrative Office of the Courts nor the National Center for Juvenile Justice bear any responsibility for the analyses or interpretations presented herein. 
$N=115$ ), and took a random sample of an equal number of girls who were retained in juvenile court. Though the sample size was relatively small, nationally the female proportion of waived cases increased from 5\% to 7\% between 1985 and 2002 [59]. As a comparison, the current study also sampled boys. Because of the larger sample of male offenders, it was necessary to take a random sample of boys who were transferred and boys retained in juvenile court. Thus the final sample contained 460 cases.

\section{Variables}

Prior research indicates that a number of variables have been found to influence transfer decisions $[27,28,60,61]$. The independent variables of primary interest to this study were the individual characteristics and legal factors. The descriptive statistics for all independent variables is included in Table 1.

The legal factors of seriousness of current offense and number of prior offenses have been found to strongly influence [62-64]. Current offense was based on crime type (the most serious offense), and dummy variables were created to distinguish between person, property, drug, and other offenses. Due to the small number of drug and other offenses, these two categories were collapsed and used as the reference category.

Earlier research also has shown that extralegal variables may have an effect on sentence outcomes. Of particular interest in the current study were the findings that girls are treated differently than boys by the juvenile justice system $[9,10,18]$. Daly (1994) suggests that there is an important difference in the severity of offending between girls and boys and asserts that the two genders might be punished differently for like crimes [65]. Gender refers to either male or female offenders. Therefore, gender was coded as (0) for male and (1) for female.

Similarly, race has been shown to significantly influence waiver decisions [35,53,66-68]. Race was coded as White, African American, Hispanic/Latino, Asian/Pacific Islander, Native American, or other. Because of the small number of Asian, Native American, and African American cases within the data, the race variable was collapsed into non-White and White.

Age also is related to transfer decisions, and prior research shows that older youth are more likely to be transferred to adult court than younger youth [17-19,62,63,69]. The youth's age at time of arrest was entered into the model as a specific number of years (continuous variable).

Prior research has found that the type of county has an impact of court outcomes [40,69]. According to census data, counties are designated as rural if the population is below 50,000 and designated as urban/suburban if the population is above 50,000 people (U.S Census Bureau, 2000). In order to obtain a more equal spread of jurisdiction, court jurisdiction was coded based on county population density, with (0) for lightly populated counties; (1) for moderately populated counties; and (2) for densely populated counties. For the purpose of this study, eight counties were coded as lightly populated, six were coded as moderately populated, and only one county coded as densely populated. 
Table 1. Frequency Distribution of Variables for Girls and Boys.

\begin{tabular}{|c|c|c|c|c|c|c|c|c|}
\hline \multirow[b]{3}{*}{ Value } & \multicolumn{4}{|c|}{ Waived } & \multicolumn{4}{|c|}{ Not Waived } \\
\hline & \multicolumn{2}{|c|}{ Girls $(N=115)$} & \multicolumn{2}{|c|}{ Boys $(N=115)$} & \multicolumn{2}{|c|}{ Girls $(N=115)$} & \multicolumn{2}{|c|}{ Boys $(N=115)$} \\
\hline & $N$ & $\%$ & $N$ & $\%$ & $N$ & $\%$ & $N$ & $\%$ \\
\hline \multicolumn{9}{|l|}{ Race } \\
\hline White & 63 & 54.8 & 40 & 34.8 & 62 & 53.9 & 62 & 53.4 \\
\hline Black & 13 & 11.3 & 12 & 10.4 & 12 & 0.4 & 7 & 6.1 \\
\hline Hispanic & 32 & 27.8 & 61 & 53.0 & 30 & 26.1 & 41 & 35.7 \\
\hline Native American & 3 & 2.6 & 2 & 1.7 & 11 & 9.6 & 3 & 2.6 \\
\hline Asian/Pacific Islander & 1 & 0.9 & 0 & 0.0 & 0 & 0.0 & 0 & 0.0 \\
\hline Other & 3 & 2.6 & 0 & 0.0 & 0 & 0.0 & 2 & 1.7 \\
\hline \multicolumn{9}{|l|}{ Current Offense } \\
\hline Person & 40 & 34.8 & 51 & 44.3 & 22 & 19.1 & 19 & 16.5 \\
\hline Property & 47 & 40.9 & 48 & 41.7 & 44 & 38.3 & 42 & 36.5 \\
\hline Drug & 26 & 22.6 & 13 & 11.3 & 34 & 29.6 & 43 & 37.4 \\
\hline Other & 2 & 1.7 & 3 & 2.6 & 15 & 15.0 & 11 & 9.6 \\
\hline \multicolumn{9}{|l|}{ School Status } \\
\hline Currently Enrolled & 43 & 37.4 & 46 & 40.0 & 74 & 64.3 & 82 & 71.3 \\
\hline Not enrolled & 72 & 62.6 & 69 & 60.0 & 41 & 35.7 & 33 & 28.7 \\
\hline \multicolumn{9}{|l|}{ Court Jurisdiction } \\
\hline Lightly populated & 28 & 24.3 & 17 & 14.8 & 16 & 13.9 & 17 & 14.8 \\
\hline Moderately populated & 12 & 10.4 & 18 & 15.4 & 45 & 39.1 & 44 & 38.3 \\
\hline \multirow[t]{2}{*}{ Densely populated } & 75 & 65.2 & 80 & 69.6 & 54 & 47.0 & 54 & 47.0 \\
\hline & Mean & $\mathrm{SD}$ & Mean & $\mathrm{SD}$ & Mean & $\mathrm{SD}$ & Mean & $\mathrm{SD}$ \\
\hline Age & 16.40 & 0.82 & 16.40 & 0.79 & 14.59 & 1.75 & 14.58 & 1.96 \\
\hline Prior Referrals & 4.56 & 5.08 & 7.59 & 6.71 & 2.00 & 3.12 & 2.97 & 4.4 \\
\hline
\end{tabular}


Education was also of interest. School status was measured as: not enrolled/attending and currently enrolled/attending. School status was coded as youth who were not enrolled in or attending school, and those currently enrolled in or attending school at the time of arrest.

The dependent variable for the model was dichotomous and was coded as transfer to adult criminal court. In this analysis, (0) represented youth not transferred and (1) represented youth who were transferred.

Based on these measures, the current study examines three hypotheses:

Ha (1): Girls will be less likely than boys to be judicially waived to adult court.

Ha (2): Girls who are waived will have less serious prior records than boys who are waived.

Ha (3): Girls who are waived will have less serious current offenses than boys who are waived.

Ha (4): Extra legal variables will have a stronger impact on girls than on boys who are waived.

$\mathrm{Ha}$ (5): Legal variables will have a stronger impact on boys than on girls who are waived.

\section{Results}

\section{Multivariate Analysis}

Table 1 presents the frequency distribution for youth who were waived and not waived to adult court. Hypothesis one predicted that girls would be less likely than boys to be judicially waived to adult court. Using official data, it is clear that the number of girls judicially waived to adult court is significantly less than the number of boys waived to adult court (121 girls versus 2529 boys). However, the full logistic model (Table 2$)$ reported no statistical significance for gender $(b=0.383, p=1.467)$.

Table 2. Logistic Regression Results for Judicial Waiver of Girls and Boys.

\begin{tabular}{ccccc}
\hline Variable & B & SE & Wald & (Exp)B \\
\hline \multicolumn{5}{c}{ Girls \& Boys $N=460$} \\
Gender & 0.383 & 0.269 & 2.048 & 1.467 \\
Race & 0.011 & 0.267 & 0.002 & 1.011 \\
Age & 1.129 & 0.136 & $69.211^{* *}$ & 3.093 \\
Jurisdiction & 0.444 & 0.268 & 2.743 & 1.559 \\
School status & -0.600 & 0.260 & $5.314^{*}$ & 0.549 \\
Person offense & 2.045 & 0.364 & $31.593 * *$ & 7.726 \\
Property offense & 1.030 & 0.309 & $11.130 * *$ & 2.802 \\
Priors & 0.155 & 0.029 & $27.684 * *$ & 1.167 \\
Constant & -19.594 & 2.287 & $73.426 * *$ & 0.000 \\
-2 Log-likelihood & 375.683 & & & \\
Cox \& Snell $R^{2}$ & 0.434 & & \\
Nagelkerke $R^{2}$ & 0.579 & & \\
Model Chi Square & 262.013 & &
\end{tabular}

Hypothesis two predicted that girls who were waived would have less serious prior records than boys who were waived. The frequency distribution of prior offenses indicated that girls waived to adult court had a fewer number of prior referrals than boys who were waived to adult court (4.6 compared 
to 7.6). Twenty-five percent of the girls waived had no prior referrals, whereas only $14 \%$ of the boys waived had no prior referrals. On average, judicially waived boys had a greater number of prior referrals than judicially waived girls.

Additionally, hypothesis three predicted that girls who were judicially waived would have been referred for a less serious current offense than boys who were waived. A greater number of girls were transferred for property offenses (40\%) rather than person offenses (34.8\%). Conversely, a larger number of boys were transferred for person offenses (43.5\%) rather than property offenses $(41.7 \%)$. The finding is consistent with prior research and arrest data that report that most girls are typically arrested for non-violent crimes as opposed to violent crimes.

Hypothesis four and five examine legal and extra legal effects. In order to accurately determine the effects these variables have on judicial waiver decisions, logistic analysis was conducted. Logistic regression models were used to assess the effects of the independent variables (gender, race, age, school status, court jurisdiction, current offenses, and prior offenses) on judicial waiver.

Table 2 presents the results of a logistic regression model containing both girls and boys. In this model, several variables appeared to be significant predictors of judicial waiver.

As shown in Table 2, legal factors, person offense, property offense, and prior referrals were all significant. The simple log odds of waiver was nearly eight times greater for youth who committed person offenses and nearly three times greater for youth who committed property offenses compared to youth who committed drug or other offenses. Prior referrals also were positively related to waiver $(\mathrm{b}=0.167, p<0.01)$. Youth with an increase of one prior referral were almost $17 \%$ more likely to be judicially waived to adult court.

When looking at extra legal variables, age was a significant predictor for waiver $(\mathrm{b}=1.129$, $p<0.01)$. The model indicated that as age increased by one year, the likelihood of waiver, or the simple odds of waiver, was three times greater for older youth than for younger youth. School status also was significant $(\mathrm{b}=-0.600, p<0.05)$ and the model indicated that the simple odds of waiver decreased by $54 \%$ for youth who were enrolled in school. Conversely, for youth who were not enrolled in school, the simple odds of judicial waiver increased by $182 \%(1 / 0.549=1.82)$. In short, youth who were not enrolled in school were more likely to be judicially waived to adult court.

Table 3 presents the results of a logistic regression model that examined the effects of legal variables on judicial waiver for girls and boys.

As presented in Table 3, all the legal variables were significant for girls and boys. The simple odds of judicial waiver was four times greater for girls convicted of person offenses $(b=1.404, p<0.01)$ and more than two times greater for girls convicted of property offenses compared to girls who committed drug or other offenses $(b=0.767, p<0.05)$. Similarly, the simple odds of judicial waiver was twelve times greater for boys convicted of person offenses $(b=2.524, p<0.01)$ and four times greater for boys convicted of property offenses $(b=1.438, p<0.01)$. Additionally, the number of priors was shown to be statistically significant for both genders. As the number of prior referrals increased, the $\log$ odds of waiver increased for girls $(b=1.194, p<0.001)$ and boys $(b=1.192$, $p<0.001)$. With each additional increase in the number of prior referrals, the simple odds of judicial waiver increased $17.7 \%$ for both girls and boys. 
Table 3. Logistic Regression Results of Legal Variables for Girls and Boys.

\begin{tabular}{ccccc}
\hline Variable & B & SE & Wald & (Exp)B \\
\hline Person offense & 1.404 & 0.308 & $13.633^{* *}$ & 4.070 \\
Property offense & 0.767 & 0.339 & $5.122^{*}$ & 2.154 \\
Priors & 0.177 & 0.042 & $17.949 * *$ & 1.194 \\
Constant & -1.227 & 0.295 & $17.395 * *$ & 0.293 \\
-2 Log-likelihood & 283.739 & & & \\
Cox \& Snell $R^{2}$ & 0.142 & & & \\
Nagelkerke $R^{2}$ & 0.189 & & & \\
Model Chi Square & 35.108 & & & \\
\hline Boys $N=230$ & & \\
\hline Person offense & 2.524 & 0.443 & $32.518 * *$ & 12.477 \\
Property offense & 1.438 & 0.403 & $12.746 * *$ & 4.213 \\
Priors & 0.176 & 0.033 & $28.141 * *$ & 1.192 \\
Constant & -2.223 & 0.381 & $34.073 * *$ & 0.108 \\
-2 Log-Likelihood & 242.036 & & & \\
Cox \& Snell $R^{2}$ & 0.284 & & & \\
Nagelkerke $R^{2}$ & 379 & & & \\
Model Chi Square & 76.811 & & & \\
\hline
\end{tabular}

Note: $* p<0.05 ; * *<0.01$.

Table 4 presents the results of a logistic regression model that analyzed the effects that extra legal variables had on judicial wavier for girls and boys. In this model, age and school status were significant predictors for both girls and boys. For both girls and boys, age was the strongest predictor for transfer.

Table 4. Logistic Regression Results of Extra Legal Variables for Girls and Boys.

\begin{tabular}{ccccc}
\hline Variable & B & SE & Wald & (Exp)B \\
\hline Race & \multicolumn{1}{c}{ Girls $N=230$} & & \\
Age & 0.107 & 0.338 & 0.101 & 1.113 \\
Jurisdiction & 1.063 & 0.169 & $39.642 * *$ & 2.896 \\
School status & 0.647 & 0.339 & 3.649 & 1.910 \\
Constant & -0.722 & 0.334 & $4.669 *$ & 0.486 \\
-2 Log-likelihood & -16.813 & 2.743 & $37.567 * *$ & 0.000 \\
Cox \& Snell $R^{2}$ & 222.453 & & & \\
Nagelkerke $R^{2}$ & 0.342 & & & \\
Model Chi Square & 0.456 & & & \\
\hline Race & 96.395 & & & \\
Age & Boys $N=230$ & & \\
Jurisdiction & -0.611 & 0.338 & 3.258 & 2.715 \\
School Status & 0.999 & 0.162 & $38.032 * *$ & 2.542 \\
Constant & 0.993 & 0.341 & $7.484 * *$ & 0.464 \\
-2 Log-Likelihood & -0.767 & 0.341 & $5.060 *$ & 0.000 \\
Cox \& Snell R & -15.343 & 2.635 & $34.786 * *$ & \\
Nagelkerke $R^{2}$ & 0.358 & & & \\
Model Chi Square & 10.478 & & &
\end{tabular}


As age increased by one year, the likelihood of judicial waiver was nearly three times greater for girls and boys. For every one year increase in age, a girl's log odds of being transferred increased by $1.063(\mathrm{~b}=1.063, p<0.001)$. Similarly, a boy's log odds of transfer significantly increased with the increase in age $(b=0.999, p<0.001)$.

Girls and boys who were enrolled in school were 51\% less likely to be judicially waived compared to youth who were not enrolled in school. Conversely, the simple odds of waiver for youth who were not enrolled in school was nearly two times greater than for girls and boys who were enrolled in school $(1 / 0.486=2.06)$. Additionally, court jurisdiction was not a significant predictor of judicial waiver for girls, but appeared to be significant for boys $(b=0.993, p<0.01)$. For boys, the simple odds of judicial waiver was $154 \%$ greater for boys in urban areas than for boys in rural jurisdictions. Interestingly, race was not a significant predictor for judicial waiver for either gender.

To adequately determine the effect of the independent variables on judicial waiver for girls and boys, z-scores were calculated (see Table 5).

Table 5. Analysis of Extra Legal and Legal Variables for Girls and Boys ( $N=230$ Girls and $N=230$ Boys).

\begin{tabular}{cccccc}
\hline Variable & Girls B & SE & Boys B & SE & I z I \\
\hline Extra Legal Variables & & & & & \\
\hline Race & 0.107 & 0.338 & -0.611 & 0.338 & 1.500 \\
Age & $1.063 * *$ & 0.169 & $0.999 * *$ & 0.162 & 0.272 \\
Jurisdiction & 0.647 & 0.339 & $0.993 * *$ & 0.341 & 0.719 \\
School status & -0.722 & 0.334 & -0.767 & 0.341 & 0.094 \\
Constant & $-16.813^{* *}$ & 2.743 & $-15.343 * *$ & 2.635 & 0.386 \\
\hline Legal Variables & & & & & \\
\hline Person offense & $1.404^{* *}$ & 0.308 & $2.524 * *$ & 0.443 & $2.074 *$ \\
Property offense & $0.767 *$ & 0.339 & $1.438 * *$ & 0.403 & 1.273 \\
Priors & $0.177 * *$ & 0.042 & $0.176 * *$ & 0.039 & 0.017 \\
Constant & -1.227 & 0.295 & $-2.223 * *$ & 0.381 & $2.066 *$ \\
\hline
\end{tabular}

Note: $* p<0.05 ; * * p<0.01$.

Examining the split model in Table 5, one of the independent variables appears to influence the two genders differently. The $z$-score for a person offense was significant $(z=2.074)$ which indicates that being arrested for a person offense affected judicial waiver for girls and boys differently. The remaining z-scores failed to reach statistical significance, indicating that the differences between girls and boys were statistically insignificant. In short, only arrest for a person offense had a different effect on girls and boys being judicially waived to adult court.

The findings presented in the previous tables fail to support hypothesis four, which predicted that extra legal variables would have a stronger impact on girls than on boys. On the contrary, because jurisdiction was shown to be significant only for boys, it would appear that extra legal variables were more significant for boys than for girls. Additionally, the previous models support hypothesis five-the expectations that legal variables also had a stronger impact on boys than on girls. 


\section{Discussion}

This study focused on the variables that influenced judicial waiver in a sample drawn from Arizona between 1994 and 2000. The independent effects of extra legal and legal factors appeared to be important. Of particular importance were the effects of age as an extra legal variable and prior referrals as a legal variable. In both instances, the effects were positive and highly significant for girls and boys. Older youth were consistently more likely to be judicially waived than younger youth. Similarly, a higher number of prior referrals was associated with a greater likelihood of judicial waiver for girls and boys.

Additionally, the type of offense also influenced the judicial waiver decision. In the mixed model of girls and boys, person, and property offenses were shown to be significant for both genders when compared to other offenses. Comparatively, person offenses were shown to be a stronger predictor of judicial waiver for boys than for girls. Boys were twelve times more likely to be judicially waived for person offenses, and girls were four times more likely to be judicially waived for person offenses.

School status was also shown to be significant. Girls and boys who were enrolled in school were less likely to be waived than those who were not enrolled. These data suggest that school attendance is an important consideration for juvenile court judges in their decision to waive girls to adult court. It is unclear why this variable is more important for girls than boys, but it might be indicative of gender stereotypes. Girls are expected to be enrolled in school, but boys are given freer reign. However, this finding suggests that school based programs designed to keep youth in school and to provide them with assistance merit greater consideration in future research.

Jurisdiction had an effect on judicial waiver decisions for boys only. Boys in densely populated jurisdictions were more likely to be judicially waived than boys in lightly/moderately populated jurisdictions. Jurisdiction was not shown to be significant for girls. Finally, gender and race were not shown to be significant predictors of judicial waiver.

While the results of this study are interesting, it is important to consider limitations before drawing conclusions about this research. First, this study examined one state in the 1990s and how it determined judicial waiver. It is possible that different findings might have occurred if more states were included in the research. Also, the author did not have access to data on other waiver procedures. Future research might consider an analysis that incorporates all the waiver procedures in one state. Second, the sample size was small, and because there were only a small number of Asian, Native American, and African American youth in the sample, these cases were combined with Hispanic youth into a non-White category. As a result, this study only compared the outcomes for White and non-White youth without taking into account the individual racial and/or ethnic characteristics and influences of each specific group. Future research might build upon these limitations. Third, the data are from the 1990s, the height of the "get tough" movement in juvenile justice. This is important when examining historical trends but should be used cautiously if making comparisons to contemporary data.

\section{Conclusions}

In examining judicial waiver, it is important to assess whether or not girls and boys are treated the same or if gender bias exists in the juvenile court's handling of youthful offenders. Judicial waiver decisions allow the judge to individualize justice and consider relevant aspects of the case such as 
severity of offense, maturity of the offender, and amenability to treatment $[47,48]$. The purpose of this study was to determine if gender bias existed in judicial waiver decisions in one state and to analyze the factors that influenced the decision to judicially waive girls. The findings presented provide a fairly complex portrait of the effects of several variables on judicial waiver. While girls appeared to be waived for lesser offenses (property offenses) and fewer prior referrals (as shown in Table 1), the overall effect of gender of judicial waiver was not supported by these data.

The results from the logistic regression analysis provided only partial support for the hypothesis that extra legal variables are a strong predictor of judicial waiver decisions for girls. In this study, legal variables are significant (current offense and the number of prior referrals). As in many studies previously discussed, the extra-legal variable, age, was found to be a predictor of waiver. The juvenile justice system was created to act in the best interest of the child. However, with the increase of youth crime and the emergence of the youthful "super-predator" in the media, the juvenile courts changed the focus from protecting the child to punishing the child. One way that the courts shifted to punishment and retribution was to increase the number of youth who were waived to adult court- primarily youth approaching the age of majority.

Based on the results of this study, age, school status, prior record, and type of offense had an effect on judicial waiver. While the purpose of waiver policies may be to deter or punish youthful offenders, pragmatic policy implications might seek to prevent such youth from offending to the point that judicial transfer is warranted. Investing in and increasing the number of delinquency prevention programs, diversion programs, and other early intervention practices might help to identify at risk youth and provide the assistance they need in order to avert their future offending.

Since age was shown to be an influential predictor in judicial waiver, it is suggested that the juvenile court age be increased to include offenders through their early $20 \mathrm{~s}$. In this respect, more youth would be allowed to take advantage of the treatment options available in the juvenile system.

Additionally, offenses against persons and property offenses were found to be the most likely to be judicially waived. It is recommended that more research examine the reasons girls commit these offenses. It is possible that substance abuse, gang involvement, and home abuse might impact the commission of these crimes [70]. Policies that seek to address the underlying causes of these offenses rather than reacting to the offense might include increasing the availability of drug, alcohol, and family counseling services. Gender-specific prevention programs are also warranted.

Probably the most important findings of this study are that judges were being objective in their use of judicial waiver. Prior research suggested that judges apply waiver decisions in an arbitrary and discriminatory manner [17]. However, these results indicate no overt cases of bias or discrimination. It was predicted that gender would influence judicial waiver decisions; however, this was not the case. Gender had no effect on waiver. Based on the results of this study, it would appear that, in general, judicial waiver was applied consistently in the state. These data suggest that juvenile court judges primarily considered the seriousness of the offense, the previous history of the offender, and the maturity or age of the youth before waiving the juvenile to adult court. This supports the notion that judges (not the legislatures or prosecuting attorneys) are in the best position to decide whether to waive juveniles to adult court [71].

There is a gap in the literature regarding girls and judicial waiver and the current study attempted to determine if gender bias exists in judicial waiver practices in one state. 
Based on this study, it is clear that more research is warranted. Further research needs to be conducted at all levels of juvenile justice system in order to gain a clearer assessment of the treatment and processing of girls. As Tracy, Kempf-Leonard, and Abramoske-James note, "Future research must include females and males, and it must examine the progression of specific offending over the lifetime but especially among the very young" ([72], p. 211). In this way appropriate interventions can be implemented to help prevent the necessity of waiver for girls and boys.

\section{Conflicts of Interest}

The author declares no conflict of interest.

\section{References and Notes}

1. Feld, Barry C. "Juvenile (in)justice and the criminal court alternative." Crime \& Delinquency 39 (1993): 403-24.

2. Feld, Barry C. "Politics of race and juvenile justice: The due process revolution and the conservative reaction." Justice Quarterly 20 (2003): 765-800.

3. Jensen, Eric J., and Linda K. Metsger. "A test of the deterrent effect of legislative waiver on violent juvenile crime." Crime and Delinquency 40 (1994): 96-104.

4. Tanenhaus, David S. Juvenile Justice in the Making. New York: Oxford University Press, 2004.

5. Zimring, Franklin E. American Juvenile Justice. New York: Oxford University Press, 2005.

6. Griffin, Patrick, Patricia Torbet, and Linda Szymanski. Trying Juveniles as Adults in Criminal Court: An Analysis of State Transfer Provisions (Report No. NCJ 172836). Washington: Office of Juvenile Justice and Delinquency Prevention, 1998.

7. Carr, Nincole T., Kenneth Hudson, Roma S. Hanks, and Andrea N. Hunt. "Gender effects along the juvenile justice system." Feminist Criminology 3 (2008): 25-43.

8. Leiber, Michael J., Sara J. Brubaker, and Kristan C. Fox. "A closer look at the individual and joint effects of gender and race on juvenile justice decision making." Feminist Criminology 4 (2009): 333-58.

9. Leiber, Michael J., and Kristin Y. Mack. "The individual and joint effects of race, gender, and family status on juvenile justice decision-making." Journal of Research in Crime and Delinquency 40 (2003): 34-70.

10. MacDonald, John, and Meda Chesney-Lind. "Gender bias and juvenile justice revisited: A multiyear analysis." Crime and Delinquency 47 (2001): 172-95.

11. Feld, Barry C. "Race, youth violence, and the changing jurisprudence of waiver." Behavioral Sciences \& the Law 19 (2001): 3-22.

12. Steiner, Benjamin. "Assessing the relative effects of state direct file waiver laws on violent juvenile crime: Deterrence or Irrelevance." Journal of Criminal Law and Criminology 96 (2006): 1451-78.

13. Steiner, Benjamin, Craig Hemmens, and Valerie Bell. "Legislative waiver reconsidered: General deterrent effects of statutory exclusion laws enacted post 1979." Justice Quarterly 23 (2006): 34-50.

14. Myers, David. Boys among Men: Trying and Sentencing Juveniles as Adults. Westport: Praeger, 2005.

15. Sanborn, John. "The adultification of youth.” In Controversies in Juvenile Justice and Delinquency. Edited by Peter Benekos and Alida Merlo. New York: Anderson Publishing, 2004, pp. 143-64. 
16. Jordan, Kareem. Getting Tough in Adult Court: A Comprehensive Examination of Legislative Waiver and Decertification. Ann Arbor: ProQuest Information and Learning Company, 2005.

17. Fagan, Jeffrey, and Elizabeth P. Deschenes. "Determinants of judicial waiver decisions for violent juvenile offenders." Journal of Criminal Law and Criminology 81 (1990): 314-47.

18. Bishop, Donna M., and Charles E. Frazier. "Gender bias in juvenile justice processing: Implications of the JJDP Act." The Journal of Criminal Law and Criminology 82 (1992): 1162-86.

19. Champion, Dean J. "Teenage felons and waiver hearings: Some recent trends, 1980-1988." Crime and Delinquency 35 (1989): 577-85.

20. Puzzanchera, Charles. Juvenile Offenders and Victims: A National Report. Washington: Office of Juvenile Justice and Delinquency Prevention, 2009.

21. Stahl, Anne L. Delinquency Cases in Juvenile Courts, 1996. Fact Sheet. Washington: US Department of Justice, Office of Justice Programs, Office of Juvenile Justice and Delinquency Prevention, 1999.

22. Stahl, Anne L. Delinquency Cases in Juvenile Courts, 1997. Fact Sheet. Washington: US Department of Justice, Office of Justice Programs, Office of Juvenile Justice and Delinquency Prevention, 2000.

23. Stahl, Anne L. Delinquency Cases in Juvenile Courts, 1998. Fact Sheet. Washington: US Department of Justice, Office of Justice Programs, Office of Juvenile Justice and Delinquency Prevention, 2001.

24. Stahl, Anne L. Delinquency Cases in Juvenile Courts, 1999. Fact Sheet. Washington: US Department of Justice, Office of Justice Programs, Office of Juvenile Justice and Delinquency Prevention, 2003.

25. Jordan, Kareem, and David L. Myers. "The decertification of transferred youth: Examining the determinants of reverse waiver." Youth Violence and Juvenile Justice 5 (2007): 188-206.

26. Dixon, Jo. "The organizational context of criminal sentencing." American Journal of Sociology 100 (1995): 1157-98.

27. Armstrong, Gaylene S., and Nancy Rodriguez. "Effects of individual and contextual characteristics on preadjudication detention of juvenile delinquents." Justice Quarterly 22 (2005): 521-39.

28. Conley, Darlene. "Adding color to a Black and White picture: Using qualitative data to explain racial disproportionality in the juvenile justice system." Journal of Research in Crime and Delinquency 31 (1994): 135-48.

29. Scarpitti, Frank R., and Richard M. Stephenson. "Juvenile court disposition: Factors in the decision making process." Crime and Delinquency 17 (1971): 142-51.

30. Belknap, Joanne. The Invisible Woman: Gender, Crime and Justice. Belmont: West/Wadsworth, 2007.

31. Sherman, Francine T. "Justice for girls: Are we making progress?" Criminal Justice 28 (2013): 9-17.

32. Chesney-Lind, Meda. "Judicial enforcement of the female sex role." Issues in Criminology 8 (1973): 51-71.

33. Datesman, Susan K., and Frank Scarpitti. "Unequal protection for males and females in the juvenile court." In Women, Crime, and Justice. Edited by Susan. K. Datesman and Frank R. Scarpitti. New York: Oxford University Press, 1980, pp. 300-18.

34. Belenko, Steven, Jane B. Sprott, and Courtney Petersen. "Drug and alcohol involvement among minority and female juvenile offenders: Treatment and policy issues." Criminal Justice Policy Review 15 (2004): 3-36.

35. Bishop, Donna. "Race, delinquency, and discrimination: Minorities in the Juvenile Justice System." In Controversies in Juvenile Justice. Edited by Alida Merlo and Peter Benekos. New York: Anderson Publishing, 2004, pp. 187-214. 
36. Chapman, John F., Rani A. Desai, Paul R. Falzer, and Randy Borum. "Violence risk and race in a sample of youth in juvenile detention: The potential to reduce disproportionate minority confinement." Youth Violence and Juvenile Justice 4 (2006): 170-84.

37. Holley, Lynne C., and Russell K. van Vleet. "Racism and classism in the youth justice system: Perspectives of youth and staff." Journal of Poverty 10 (2006): 45-67.

38. Hsia, Heidi M., and Donna Hamparian. "Disproportionate minority confinement: 1997 update." In Juvenile Justice Bulletin. Washington: U.S. Department of Justice, Office of Justice Programs, Office of Justice and Delinquency Prevention, 1998.

39. Hsia, Heidi. “OJJDP Formula Grants Program.” In Juvenile Justice Bulletin (\#112). Washington: U.S. Department of Justice, Office of Justice Programs, Office of Justice and Delinquency Prevention, 1999.

40. Johnson, David R., and Laurie K. Scheuble. "Gender bias in the disposition of juvenile court referrals: The effects of time and location.” Criminology 29 (1991): 677-99.

41. Lieber, Michael J. "Disproportionate Minority Confinement (DMC) of youth: An analysis of state and federal efforts to address the issue." Crime \& Delinquency 48 (2002): 3-46.

42. Sickmund, Melissa, Anthony Sladky, and Wei Kang. "Easy Access to Juvenile Court Statistics: 1985-2013." 2015. Available online: http://www.ojjdp.gov/ojstatbb/ezajcs/ (accessed on 10 February 2015).

43. Snyder, Howard N., and Melissa Sickmund. Juvenile Offenders and Victims: 1999 National Report. Washington: Office of Juvenile Justice and Delinquency Prevention, 1999.

44. Hoge, Robert D., Donald A. Andrews, and Allen W. Leshied. "Investigation of variables associated with probation and custody dispositions in a sample of juveniles." Journal of Clinical Psychology 34 (1995): 279-86.

45. Poole, Eric, and Robert Regoli. "An analysis of juvenile court dispositions.” Juvenile and Family Court Journal 31 (1980): 23-32.

46. Steffensmeier, Darrell, Jeffrey Ulmer, and John Kramer. "The interaction of race, gender, and age in criminal sentencing: The punishment costs of being young, Black, and male." Criminology 36 (1998): 763-98.

47. Feld, Barry C. "A funny thing happened on the way to the centennary: Social structure, race, and the transformation of the juvenile court." Punishment \& Society 1 (1999): 187-214.

48. Del Carmen, Ronaldo V., Mary Parker, and Frances P. Reddington. Briefs of Leading Cases in Juvenile Justice. Cincinnati: Anderson Publishing, 1998.

49. Chesney-Lind, Meda. "Paternalism and the female status offender." Crime \& Delinquency 23 (1977): 121-30.

50. Chesney-Lind, Meda. "Women and crime: The female offender." Signs 12 (1986): 78-96.

51. Chesney-Lind, Meda. "Patriarchy, crime and justice: Feminist criminology in an era of backlash." Feminist Criminology 1 (2006): 6-26.

52. Sharp, Christy, and Jessica Simon. Girls in the Juvenile Justice System: The Need for More Gender-Responsive Services. Washington: Child Welfare League of America, 2004.

53. Snyder, Howard N., and Melissa Sickmund. Juvenile Offenders and Victims: 2006 National Report. Washington: U.S. Department of Justice, Office of Justice Programs, Office of Juvenile Justice and Delinquency Prevention, 2006. 
54. Bergsmann, Ilene. "The forgotten few: Juvenile female offenders." Federal Probation 53 (1989): $73-78$.

55. Smith, Cindy J., and Kimberly S. Craig. "Profiles of judicially waived youth." Corrections Today 66 (2004): 28-63.

56. Podkopacz, Marcy R., and Barry Feld. "The end of the line: An empirical study of judicial waiver." Journal of Law \& Criminology 86 (1996): 449-92.

57. Barry Feld. "Violent Girls or Relabeled Status Offenders? An Alternative Interpretation of the Data." Crime \& Delinquency 55 (2009): 241-63.

58. National Center for Juvenile Justice. Arizona Juvenile Court Case Records: 1994-2000 [machine-readable data files]. Data collected by the Arizona Supreme Court, Administrative Office of the Courts. Data were provided to the National Juvenile Court Data Archive, National Center for Juvenile Justice, where they were revised for research use under grants \#95-JN-FX-0008 and \#1999-MU-MU-0020 from the Office of Juvenile Justice and Delinquency Prevention, U.S. Department of Justice. Phoenix, AZ: Arizona Supreme Court, Administrative Office of the Court [producer]. Pittsburgh, PA: National Juvenile Court Data Archive, National Center for Juvenile Justice [distributor].

59. Stahl, Anne, Terrence Finnegan, and Wei Kang. "Easy Access to Juvenile Court Statistics: 1985-2002." 2006. Available online: http://ojjdp.ncjrs.gov/ojstatbb/ezajcs/ (accessed on 10 February 2015).

60. Jordan, Kareem L., and Tina L. Freiburger. "Examining the impact of race and ethnicity on the sentencing of juveniles in the adult court." Criminal Justice Policy Review 21 (2010): 185-201.

61. Lemmon, John H., Thomas L. Austin, Philip J. Verrecchia, and Matthew Fetzer. "The effect of legal and extralegal factors on statutory exclusion of juvenile offenders." Youth Violence and Juvenile Justice 3 (2005): 214-34.

62. Clarke, Elizabeth E. "A case for reinventing juvenile transfer: The record of transfer of juvenile offenders to criminal court in Cook County, Illinois." Juvenile and Family Court Journal 47 (1996): 3-21.

63. Clement, Mary J. "A five-year study of juvenile waiver and adult sentences: Implications for policy." Criminal Justice Policy Review 8 (1997): 201-19.

64. Myers, David L. "Adult crime, adult time: Punishing violent youth in the adult criminal justice system.” Youth Violence and Juvenile Justice: An Interdisciplinary Journal 1 (2003): 173-97.

65. Daly, Kathleen. Gender, Crime, and Punishment. New Haven: Yale University Press, 1994.

66. Bortner, M. A., Marjorie S. Zatz, and Darnel F. Hawkins. "Race and transfer: Empirical research and social context." In The Changing Borders of Juvenile Justice: Waiver of Juveniles to the Criminal Court. Edited by Jeffrey Fagan and Frank E. Zimring. Chicago: University of Chicago Press, 2000, pp. 277-320.

67. Puzzanchera, Charles, Anne L. Stahl, Terrance A. Finnegan, Nancy Tierney, and Howard N. Snyder. Juvenile Court Statistics 2000. Pittsburgh: National Center for Juvenile Justice, 2004.

68. Tatum, Becky. "Trying juveniles as adults: A case of racial and ethnic bias?" In Racial Issues in Criminal Justice: The Case of African Americans. Edited by Marvin D. Free. Westport: Praeger Publishing, 2003, pp. 159-75. 
69. Myers, David L. Excluding Violent Youths from Juvenile Court: The Effectiveness of Legislative Waiver. El Paso: LFB Scholarly Publishing, 2001.

70. Chesney-Lind, Meda, and Lisa Pasko. The Female Offender: Girls, Women, and Crime, 3rd ed. Thousand Oaks: Sage, 2013.

71. Keenan, Sheri J., Jeffry P. Rush., and Kelly A. Cheeseman. "Judicial waiver decisions in two southern states: A study of judicial perceptions." American Journal of Criminal Justice 40 (2015): 100-15.

72. Tracy, Paul E., Kimberly Kempf-Leonard, and Stephanie Abramoske-James. "Gender differences in delinquency and juvenile justice processing.” Crime \& Delinquency 55 (2009): 171-215.

(C) 2015 by the author; licensee MDPI, Basel, Switzerland. This article is an open access article distributed under the terms and conditions of the Creative Commons Attribution license (http://creativecommons.org/licenses/by/4.0/). 